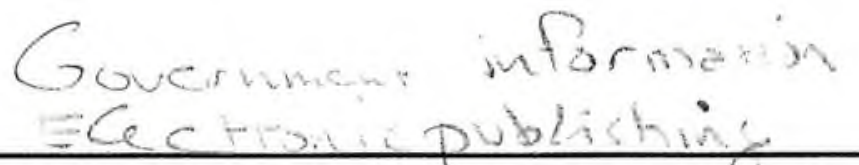

\title{
Is government information in your
}

\section{library's future?}

By Harold B. Shill

Evansdale Librarian

West Virginia University

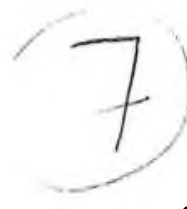

and Sandra K. Peterson

Documents Librarian

Yale University

\section{The politics of electronic dissemination, 1989.}

$\mathbf{T}$

he Federalgovernment has quietlyemerged as the world's largest electronic publisher. A 1987 General Accounting Office report listed 7,500 electronic information "products" being produced by Federal agencies. ${ }^{1}$ At the same time the number of printed publications provided by Federal agencies has declined from 16,000 to 12,000 during the 1980s. ${ }^{2}$

Clearly, the Federal government is undergoing a metamorphosis which will profoundly affect government information users, libraries of all types, and the agencies themselves. Access to the vast lode of government generated statistics, reports, regulations, studies, laws, and graphic information sources can either be greatly enhanced or greatly reduced, depending on policy choices made by Congress and Executive Branch agencies in 1989. Individuals and organizations using government information for such diverse purposes as market

'U.S. General Accounting Office, Survey of Federal Agencies, 1987 (Washington, D.C.: Government Printing Office, 1987).

${ }^{2}$ Less Access to Less Information By and About the U.S. Government: Part 2, A 1985-86 Chronology, January 1985-December 1986 (Washington, D.C.: American Library Association, Washington Office, 1986), 1. research, health care planning, demographic analysis, public policy development, governmental performance monitoring, and the location of reliable data about all types of societal trends will be affected, as will be the libraries which so often serve as the primary access points to that data.

The vehicles through which these decisions will be made-Paperwork Reduction Act reauthorization, legislative review of Title 44 U.S.C., and the possible redrafting of OMB Circular A-130-lack the high drama of the Oliver North trial, judicial review of Roe $v$. Wade, or the initial flight of the Stealth bomber. However, decisions made in the next few weeks will significantly: 1) determine future access to government information in electronic format for libraries, their users, and the general public and 2) shape Federal information policy in the coming electronic era.

Since many of the critical decisions involving electronic dissemination of government information (EDI) may be made very shortly, it is vital that academic and research librarians understand the issues and stakes involved. This paper will explore the background of the EDI controversy, examine the issues and initiatives which have emerged in 1989 , and suggest actions which might be taken by concerned librarians to affect the outcome of the EDI controversy. 


\section{Background}

Although the Depository Library Program(DLP) is the Federal information dissemination program most familiar to the library community, it is only one of numerous dissemination channels for government information and provides access to only about 50 percent of the publications produced by civilian agencies. Other direct dissemination vehicles include the National Technical Information Service (NTIS), the Superintendent of Documents Sales Program, the Consumer Information Center (CIC), private sector contractors, and Federal agenciesthemselves. The Department of Energy (DOE), Department of Defense (DOD), and the National Aeronautics and Space Administration (NASA) have particularly large dissemination programs.

Major intermediaries-depository libraries, commercial vendors, and the press-are critical, secondary disseminators within the existing dissemination infrastructure. These intermediaries complement the direct dissemination programs by providing local access, a comprehensive collection, permanent archiving and user assistance (libraries); by further processing government information and using electronic technologies to provide more sophisticated access (commercial vendors); and by identifying and publicizing information having political, social, or economic significance (the press). Viewed collectively, the direct dissemination programs and nongovernmental intermediaries comprise a complex communications infrastructure.

Existing dissemination programs are based either on statutes creating government-wide dissemination requirements (Depository Act of 1962, Freedom of Information Act, etc.) or on obligations resulting from specific legislation (National School Lunch Act, Surface Mining Control and Reclamation Act, Emergency Planning and Community Right-to-Know Act, etc.). However, and this point lies at the crux of the current debate, most existing dissemination statutes were drafted in the preelectronic era. As a result, it has been argued, printera dissemination requirements are either unclear about agencies' obligations to disseminate electronic information through existing channels or do not apply to Federal, as well as some Congressional, agencies at all.

This uncertainty has already had an undermining effect on the Federal dissemination infrastructure. First, Federal agencies themselves frequently view dissemination laws as applying to printed information only. Accordingly, electronic "products" are made available primarily to internal agency users, are disseminated (if at all) only to participants in the agencies' own dissemination networks, are not identifiable through standard bibliographic tools (Monthly Catalog, Government Reports Announcements and Index, etc.), and are not read- ily available to potential users through the DLP and other libraries.

Second, defining electronic information as a commodity which could effectively and profitably be disseminated through commercial channels, some private sector intermediaries have contended that government EDI programs would create "unfair competition" with their own business activities. These firms and the Information Industry Association (IIA) tend to view government EDI efforts as wasteful and undercutting their own services if the Federal government provides information at no cost or at prices substantially below private market rates. $^{3}$

Third, while some agencies have perceived the relevance of including electronic products in existing government-wide dissemination programs, such as the DLP, their efforts to use those programs have been delayed by the ongoing EDI debate. This outcome was most evident in the two-year delay, from 1987 to 1989 , in the creation of DLP pilot projects recommended by the Joint Committee on Printing's Ad Hoc Committee on Depository Library Access to Federal Automated Databases. The original plan to include 16 electronic products from different agencies was scaled back to five databases by the time the first product, Census Text Disk \#2, was sent to depository libraries in April 1989. The NTIS privatization debate also delayed that agency's efforts to modernize its operations and to implement strategic planning for EDI systems.

\section{Technological and political factors}

The emergence of the EDI controversy in the late 1980 s resulted from a convergence of technological and political developments.

Libraries have provided online access to government and private sector databases alike since the early 1970 s. However, the rapid proliferation of microcomputers, modems, communications software, desktop publishing systems, optical scanners, and other new information technologies in the 1980 s has radically automated and decentralized the information environment. Direct end-user access to machine-readable information from remote locations is a trend which can be expected to accelerate rapidly.

The Federal government's integration of new information technologies into its day-to-day operations has been impressively documented in Informing the Nation: Federal Information Dissemi-

\footnotetext{
${ }^{3}$ Statement of Kenneth B. Allen before the Subcommittee on Government Information, Justice and Agriculture, Committee on Government Operations, U.S. House of Representatives, April 18,1989, p. 10.
} 
nation in an Electronic Age, a landmark study released by the Congressional Office of Technology Assessment (OTA) in October 1988. ${ }^{4}$ However, as the OTA study notes, the use of electronic technologies for information dissemination has been confined largely to direct agency-to-user programs and dissemination programs run by private firms. In contrast, materials included in the central dissemination programs (DLP, NTIS, etc.) are still largely in printed or microfiche formats. ${ }^{\overline{5}}$

Lacking a statutory mandate or clearly defined guidelines to do otherwise, agencies are not actively making their electronic products available through the central dissemination mechanisms. Instead, they have increasingly made use of their own programs or of commercial vendors for dissemination. When this occurs, there is a loss of bibliographic control, substantial user fees may be imposed, information without a high commercial market value may be lost, and the role of libraries as impartial, nonprofit intermediaries is diminished. Clearly, while EDI offers great opportunities for enhancing access to government information, the Federal government's increasing reliance on electronic technologies also raises the risk that valuable information will be difficult to find, permanently lost, or available only to those able to afford substantial user fees.

Politically, a number of factors have caused EDI to emerge as an issue. They include: 1) the Reagan Administration's less-government philosophy; 2) specific directives implementing that philosophy; 3) commercial firms' interest in the profit potential of some government information; 4 ) the deficit reduction problem; 5) concerns about foreign access to sensitive information; 6 ) the emergence of the international competitiveness issue; and 7) concerns about equal access to government information.

Legally, the EDI controversy is rooted in conflicting interpretations of the 1980 Paperwork Reduction Act, the Freedom of Information Act (FOIA), policy directives from the Office of Management and Budget (OMB), and proper public/ private sector roles in electronic dissemination. One court decision (INS v. Chadha, 1983) also has been cited to question the authority of the Government Printing Office, a legislative agency, to mandate the inclusion of executive publications in the DLP.

One of the Reagan Administration's first acts in 1981 was a moratorium on the issuance of new government publications. On April 21, 1981, OMB

${ }^{4}$ U.S. Office of Technology Assessment, Informing the Nation: Federal Information Dissemination in an Electronic Age (Washington, D.C.: Government Printing Office, 1988).

${ }^{5}$ Ibid., 27. issued a directive that $F$ ederal agencies conduct a comprehensive review of existing publications to eliminate waste and duplication. A series of further OMB bulletins and circulars followed. The bestknown of these initiatives, "Reform 88 ," noted that agencies had not done enough to reduce their publication programs and mandated that 16 percent of all government periodicals and pamphlets be eliminated. ${ }^{6}$

"Reform 88 " was followed by the revision of OMB Circular A-76 (performance of commercial activities) in 1983, increased emphasis on the application of the Eisenhower-era Circular A-25 (user fees), and a revision of Circular A-3 (control of government periodical publications), originally issued by the former Bureau of the Budget in 1922 . Circular A-76 directed agencies to study services which could be performed by private firms, including libraries and information services, for contracting out. The libraries of the Departments of Energy, Labor, and Housing and Urban Development, and the National Oceanic and Atmospheric Administration (NOAA), among others, have been contracted out to private firms under this regulation. However, five efforts to contract out NTIS operations in the early 1980 s failed to demonstrate that the specific functions of that agency could be performed at less cost by the private sector.

Circular A-25, issued in 1959 by the former Bureau of the Budget (OMB's predecessor), permits Federal agencies to impose charges for individuals receiving special benefits which are not accorded to the general public from Federal programs. Such user fees were to be based on the actual cost to the government of providing such special services. Circular A-3 originally provided guidelines for agency periodical publishing programs. In May 1985, however, OMB issued a revised Circular A-25 which "provided that an OMBapproved control system (as directed in OMB Bulletin 81-16) to monitor publications programs be continued, that only those periodicals necessary to conduct public business required by law be approved, and that publications be prepared and disseminated as cost effectively as possible."

The OMB pronouncement with the most farreaching implications, however, has been Circular A-130, released in final form on December 12, 1985. Citing the Paperwork Reduction Act, various other statutes and previous OMB and Presidential

${ }^{6}$ Peter Hernon and Charles R. McClure, Federal Information Policies in the 1980's: Conflicts and Issues (Norwood, N.J.: Ablex Publishing Corp., 1987), 232, 234-36.

${ }^{7}$ Richard Laska, "Discussion Forum: Initiation of User Fee Program by Federal Agencies," Government Information Quarterly, 6, no.2 (1989): 121-23. 
directives as its authority, Circular A-130 mandated that Federal agencies: 1) produce and disseminate information only to the extent required by statute; 2) make cost-benefit assessments of information products; 3 ) utilize maximum feasible reliance on the private sector for information dissemination; 4) not offer products or services in competition with those being offered or which might potentially be provided by the private sector; and 5) impose user fees to recover costs wherever possible. ${ }^{8}$ Circular A-130 clearly represented a philosophical shift away from active dissemination toward passive, fee-based "distribution on demand" to those with the knowledge and resources to locate and acquire Federal information.

$O M B$ 's privatization policies received a major test with the Administration's 1986-88 effort to privatize the entire NTIS. The Department of Commerce's April 28, 1986, announcement in the Federal Register of plans to consider "contracting out" that agency'soperations drew immediate, sharp criticism from the library, user, and industrial research communities. In fact, 90 percent of the letters received from a broad cross-section of users and intermediaries during a 45-day comment period opposed the proposal. ${ }^{9}$ Nevertheless, the Administration proceeded doggedly with its efforts to privatize the agency despite recommendations to the contrary by a Commerce Department Task Force on NTIS Privatization, hearings investigating the privatization issue by the House Subcommittee on Science, Research, and Technology, and bans on NTIS privatization inserted in legislation passed separately by the House and Senate in 1987. That initiative was finally defeated by prohibitory provisions in the trade bill and the National Institute of Standards and Technology (NIST) authorization bill in 1988 after a final attempt was made to privatize NTIS as a pilot employee stockownership program! $!^{10}$

Although the Administration has failed in its attempts to contract out NTIS operations, it has succeeded in some areas. OMB Circular A-130 still stands as a binding policy directive for all executive branch agencies. Initiatives to disseminate Department of Agriculture (USDA) and Securities and Exchange Commission (SEC) information through

${ }^{8}$ U.S. Office of Management and Budget, Circular No. A-130, "Management of Federal Information Resources," Dec. 12, 1985.

${ }^{9}$ U.S. National Technical Information Service, NTIS Privatization Study Responses to April 28, 1986 Federal Register Notice Request for Public Comment (Springfield, Va.: National Technical Information Service, 1986). PB86-211240.

${ }^{10}$ U.S. Department of Commerce, "Request for Information: Privatization of the National Technical Information Service," Jan. 20, 1988. commercial vendors have already been undertaken . OMB vigorously opposed an effort in early 1989 by the independent Federal Maritime Commission (FMC) to make shippers' tariff filings directly available through an agency dissemination program, even though the shipping industry favored the FMC proposal. The Department of Commerce, citing the Paperwork Reduction Act and A-130 as the policy instruments guiding its planning effort, solicited public comment on its own proposal for electronic dissemination programs in August 1988. ${ }^{.1}$

In the midst of this general withdrawal from a stance supporting active dissemination programs, the Federal government has taken several accessenhancing initiatives. In 1987 President Reagan issued Executive Order 12591, a directive promoting transfer of federally developed technologies from government laboratories to the industrial and academic research sectors. The Japanese Technical Literature Act of 1986 created a new program for enhancing access to foreign technical information, reflecting concern with the U.S. competitive position in the world economy. Finally, the Glenerin Declaration committed the United States, Canada, and Great Britain to lowering barriers that diminished access to information within their own countries and between themselves.

On balance, however, agencies have been discouraged from undertaking new initiatives, forced to justify existing programs, encouraged to impose user fees, prodded to expand use of private firms for dissemination, and generally been moved toward a stance emphasizing minimal availability requirements rather than active dissemination. This shift has occurred without regard to dissemination format, but it establishes the structure under which EDI programs will develop unless Congress provides clear guidance to the contrary.

\section{Activities and issues in 1989}

\section{Office of Management and Budget}

The year began with a request by the Office of Management and Budget for comments on its "Advance Notice of Further Policy Development on Dissemination of Information"; ${ }^{2}$ the proposed policy supplemented guidance found in $\mathrm{OMB}$ Circular A-130 and incorporated OMB Circular A3. Many in the library, Federal agency, Congressional, and public interest communities believed that it would have reduced the public's ability to obtain government information in electronic for-

"Proposed Commerce Policies on Dissemination of Information in Electronic Format. (Washington, D.C.: U.S. Department of Commerce, August 5, 1988).

${ }^{12}$ Federal Register 54, no.2 (January 4, 1989): 214-20. 
mat. OMB received over two hundred letters of comment on the notice, over two-thirds of them from librarians.

In June OMB formally withdrew the earlier notice and issued the "Second Advance Notice of Further Policy Development on Dissemination of Information." ${ }^{13}$ In this notice OMB restated its fundamental philosophy as "the obligation of government to make information readily available to the public on equal terms to all citizens; that to the extent the flow of information from the government to the public can be enhanced by the participation of the private sector, such participation should be encouraged; and that participation by the private sector supplements [emphasis added] but does not replace the obligations of government. These principles apply whatever the form, printed, electronic [emphasis added], or other, in which the information has been collected or stored."14

OMB plans to proceed with the development of a new draft policy statement that will reformulate both information collection and information dissemination policy, including the pertinent sections of OMB Circular A-130, the January 1989 notice, and its notice of August 7, 1987, ${ }^{15}$ concerning electronic collection of information.

The Paperwork Reduction Act also mandated $\mathrm{OMB}$ to provide advice and guidance to Federal agencies on the acquisition and use of automatic data processing, telecommunications, and other information technology for managing information resources. In May 1989, OMB, citing this authority, requested public comments on a proposal to establish a Center for Information Technology Management. ${ }^{16}$ The purpose of such a center would be to provide agencies with advice and assistance regarding the technical management of major government information technology initiatives, not to design or build systems, or provide other functions already available from other sources.

Most of OMB's information resource management activities during the past eight years have been initiated under the authority of the Paperwork Reduction Act (PRA). Authorization for the PRA (U.S.C. 44, Chapter 35) expires September 30, 1989, forcing some legislative action on the Act. A consensus is growing among all interested parties that the language of the printing laws, Title 44, Chapter 3 (Government Printing Office), Chapter 5 (production and procurement of printing and

\footnotetext{
${ }^{13}$ Federal Register 54, no. 114 (June 15, 1989): $25554-59$.

${ }^{14}$ Ibid., 25557.

${ }^{15} \mathrm{Federal} \mathrm{Register} \mathrm{52,} \mathrm{no.152} \mathrm{(August} \mathrm{7,} \mathrm{1987):}$ 29454-57.

${ }^{16}$ Federal Register 54, no.96 (May 12, 1989): 20661
}

binding), Chapter 19 (Depository Library Program) needs updating to reflect technological changes. All of these factors have combined to generate a lot of interest on Capitol Hill in revising Title 44.

\section{Congress}

At least three Congressional committees/subcommittees are actively discussing revisions. In April 1989 the Subcommittee on Government Information, Justice and Agriculture, House Government Operations Committee ${ }^{17}$ began a series of hearings on Federal information policies and practices. The purpose of the hearings was to review current issues relating to: 1) FOIA; 2) dissemination of Federal government information through electronic means; and 3) the apparatus for establishing $\mathbf{F e d e r a l ~ i n f o r m a t i o n ~ d i s s e m i n a t i o n ~ p o l i c i e s . ~}$ Congressman Wise has introduced H.R. 2381 to amend Title 44, U.S.C. to reform the information dissemination policy functions of the Director of OMB. Sections of this bill have been incorporated into the Paperwork Reduction Act reauthorization legislation which has been drafted by the full Committee.

The full Government Operations Committee ${ }^{18}$ conducted hearings on these issues on July 20 and 27 , August 1 and 2 . Conyers has drafted a bill to reauthorize PRA; however, the draft may be published as a committee print without a bill number. The form of publication selected might indicate the direction which the Committee will take in the final analysis. Most of the provisions of H.R. 2381 were incorporated into the draft of the Conyers' proposed bill which was available in late July. The Working Group on Government Information Policy, in which the Association of Research Libraries, ALA, and other public interest groups have participated, has reviewed and commented on several drafts of Conyers' proposed legislation as well as drafts of H.R. 2381.

The Subcommittee on Procurement and Printing, House Administration Committee ${ }^{19}$ conducted hearings in May and June to review the printing chapters of Title 44, U.S.C., because of changes in electronic information format, distribution, and technology. Witnesses from agencies and representatives from the library community, the information industry, the printing industry, and the public interest groups testified; Bates has drafted

${ }^{17}$ Bob Wise, D-WV, Chair, Subcommittee on Government Information, Justice and Agriculture, House Government Operations Committee.

${ }^{18}$ John Conyers, Jr., D-MI, Chair, House Government Operations Committee.

${ }^{19} \mathrm{Jim}$ Bates, D-CA, Chair, Subcommittee on Procurement and Printing, House Administration Committee. 
bills providing for a major revision of Title 44 and a GPO-NTIS merger; he plans to introduce one or more bills this year.

On the Senate side, the Governmental Affairs Subcommittee on Government Information and Regulation $\mathrm{s}^{20}$ has also conducted hearings to examine the quality and uses of the Federal information infrastructure and to consider the reauthorization of the Paperwork Reduction Act, including consideration of changing information technology, electronic dissemination and management issues. Bingaman is expected to introduce legislation to reauthorize the Paperwork Reduction Act sometime this fall.

\section{Government Printing Office}

An unexpected contribution to the EDI debate came from Grant D. Moy Jr., GPO's General Counsel, on May 22, 1989, when he issued an opinion which authorized GPO to distribute Federal agency publications in electronic format to depository libraries. ${ }^{21}$ This disapproves a 1982 GPO General Counsel's opinion which suggested that only traditionally printed publications could be made available to depository libraries.

GPO's long-awaited electronic dissemination pilot projects finally received congressional approval for implementation in May 1989. The five pilot project participants remaining include the Bureau of the Census, Joint Committee on Printing, Environmental Protection Agency, Department of Commerce, and the Department of Energy. The projects include three CD-ROM products (the various censuses, the Toxic Release Inventory, the Congressional Record) and two online products (the Commerce Department's Electronic Bulletin Board and Energy Research Abstracts).

The National Commission on Libraries and Information Science (NCLIS) joined the list of players in July by holding a public hearing to consider the trends which the OTA report addresses. Representatives from the library and information industry communities were among those whotestified.

\section{Issues}

By now it must be obvious that there has been considerable discussion in Washington recently on Federal information policies and practices. Most of the interested parties agree on at least two broad principles:

\footnotetext{
${ }^{20}$ Jeff Bingaman, D-NM, Chair, Subcommittee on Government Information and Regulation, Senate Governmental Affairs Committee.

${ }^{21}$ U.S. Government Printing Office, GPO Dissemination of Federal Agency Publications in Electronic Format, memorandum dated May 22, 1989.
}

- The Federal government has an affirmative obligation to disseminate electronic as well as printed government information to the public in a useful manner and at a reasonable cost.

- Public access to both printed and electronic government information is a public right and a principal function and goal of Federal government information policy. Thus, electronic information dissemination systems should serve the governmental mission of informing the public, as well as enhance the ability of the public to access government information.

It is in the how and who of translating these principles into public policy embodied in Title 44 , U.S.C., that there are concerns and differences. Primary among the concerns is the definition of authority for $\mathrm{OMB}$ in government information dissemination. H.R. 2381 provides a broad mandate and centralizes authority over all Federal agencies for implementation of information management (including dissemination) functions with the director of OMB. Centralized responsibility for information management must be weighed against the potential for bureaucratic stifling of effective agency application of information technologies and the potential for misuse of power that inhibits information flow. We also must consider how placing a broad mandate which encompasses oversight of information collection, regulatory review, budgetary oversight, and enforcement powers in a single agency will impact $F$ ederal information programs. The track record of $\mathrm{OMB}$, despite their recent statement of fundamental philosophy, has not been supportive of information dissemination programs. The experience of the Federal Maritime Commission is only one of many instances in which $\mathrm{OMB}$ has operated to minimize the government role in information dissemination at the expense of public access.

Second among the issues with which the library community should be concerned is the obligation of the Federal government to disseminate its information and to maintain a diversity of sources for government information and a diversity of access points. OMB Circular A-130 clearly instructed agencies to place maximum feasible reliance on the private sector. This provision in OMB Circular A130 needs to be corrected. Furthermore, in September $1988 \mathrm{OMB}$ instructed Federal agencies that they need not comply with the Depository Library Law (Section 1902, Title 44 U.S.C.) for information products in electronic formats. OMB's position on this issue has not changed; in their Second Advance Notice of Further Policy Development on Dissemination of Information they continue to affirm that GPO may not require Federal agencies to provide electronic format products to depository libraries.

Many in the library community recognize that 
partnerships between non-profit organizations, libraries, or commercial vendors and the Federal government may indeed serve the public interest. But it is generally agreed that any partnership adopted by a Federal agency to supplant its own operation for information dissemination should be accompanied by a publicly available contract that explicitly details how Congressional mandates in support of public availability of information will be fulfilled. The test is not whether a for-profit firm could sustain an information product if the government did not have a similar product, but rather whether there is a legitimate governmental role and public need in creating and distributing information products.

Finally, there is concern about the role which the Government Printing Office will have in relation to dissemination of print and electronic executive agency products. Amendments or revisions to the Paperwork Reduction Act should be consistent with other sections of Title 44, i.e., Chapter 17 which requires GPO to index and catalog government publications; and Chapter 19 , which provides for the depository library program.

\section{Implications and outcomes}

What are the implications and possible outcomes from the proposals and discussions currently taking place? Possibly the most negative outcomewould be to maintain the status quo! More and more Federal government information is being collected and disseminated electronically. The 7,500 electronic information products listed in the General Accounting Office study were not available through traditional dissemination programs such as the GPO sales program, the depository library program, or the Consumer Information Center. The latter are the programs which Congress established to provide public access to government information. Unless a very clear message is directed to Federal agencies that the depository library program is an essential information dissemination channel and that electronic information is a part of that program, depository libraries no longer will be able to provide users with the information they need. Furthermore, as each additional Federal agency negotiates for its own dissemination program, bibliographic control of what is available, from whom it is available, and for how much is lost.

More importantly, if the private sector becomes the only source for government information, at least two outcomes are of concern to all of us. First of all, the balance of power in our society may shift. Information is power. And only those who can afford to pay for it will have it. Secondly, not all Federal government information in electronic format will be economically viable. Will we continue to have access to information on the environment, our health, and our educational system? Unless we have diverse sources and access points for government information, all of us stand to lose.

Of course, there are costs associated with electronic dissemination of government information just as there are costs associated with being a depository library for print and microform materials. Depository libraries have traditionally assumed the costs of space, equipment, staff, and training while the Federal government provided the information, i.e., print or microfiche. Although the actual costs of operating a depository library have not been fully documented, it has never been inexpensive. More than 50 percent of the depository libraries are located in institutions with less than 500,000 volumes. ${ }^{22}$

Possible outcomes of Title 44 revisions might be a restructuring of the depository program and/or partial subsidization by the Federal government. In Informing the Nation, OTA suggests two alternative futures for the depository library program. One of the futures suggested is a restructured depository library program similar to an ARL proposal which included three levels of collections and services within the depository program. ${ }^{23} \mathrm{Technol}-$ ogy provides new opportunities for making information available. The premise on which the depository library program was founded, i.e., geographic location and physical access, becomes far less important with electronic dissemination.

\section{Action needed}

As noted earlier the authorization for the PRA expires at the end of September 1989. Ideally, reauthorization would occur this year. But all three subcommittee chairs are new to their positions, as are many members of their staffs, and their responsibilities are many and varied. So although PRA took nearly two years to reauthorize in 1984, the best course of action is to be prepared.

Carefully review the documentation involved in the discussions, (H.R. 2381, OMB Circular A-130, Second Advance Notice of Further Policy Development on Dissemination of (nformation) and consider the issues involved. After you have educated yourself, then initiate discussions of the issues with your faculties, library colleagues, students, and members of Congress. It is critical that members of

${ }^{22}$ U.S. Congress, Joint Committee on Printing, Provision of Federal Government Publications in Electronic Format to Depository Libraries (Washington, D.C.: Government Printing Office, 1984), 59.

${ }^{23}$ U.S. Office of Technology Assessment, Informing the Nation: Information Dissemination in an Electronic Age (Washington, D.C.: Government Printing Office, 1988), 158. 
Congress, especially those who are members of the Subcommittees/Committees involved in the reauthorization of PRA or any other Title 44 revisions, know how their communities, congressional districts, and constituents use government information, why the depository library program is important, and why electronic dissemination of information by the Federal government is critical to the economic and social well-being of their congressional districts.

Monitor and record examples of your own and your users' problems, barriers, or other difficulties encountered in using Federal government information. The U.S. General Accounting Office (GAO) is conducting a survey and evaluation of Federal agencies' information dissemination programs. GAO is interested in establishing a contact within libraries or institutions who would be willing to discuss experiences with Federal agency dissemination programs. They are specifically interested in comments about information dissemination activities of the U.S. Department of Agriculture, the Environmental Protection Agency, and the Federal Maritime Commission but will welcome other comments as well. Although the stated deadline for this survey was July 31,1989 , GAO has indicated an interest in receiving comments throughout 1989. If you can identify someone within your institution or a user outside the academic community who is willing to participate, call or write to Kennard Thompson, U.S. General Accounting Office, Room 6905, 441 G Street, N.W., Washington, D.C. 20548; (202) 275-8018.

Electronic dissemination of government information, as with other types of information, is changing the ways in which information and our libraries are being used. The staff time, level and types of expertise, quantity and diversity of both hardware and software necessary to assist users has increased. Title 44 revisions, including electronic dissemination of government information, will have some impact on all libraries, so careful attention should be given to the discussions, papers, and legislative proposals now underway if an information infrastructure promoting access to Federal information in all formats is to be preserved into the electronic era.

\section{Copyright update}

\section{Copyright litigation}

On April 25 of this year, eight publishers filed a suit against Kinko's Graphic Corporation alleging massive violation of the fair use provision of the 1976 Copyright Act. Citing the national chain of photocopy stores with illegally copying large sections of copyrighted works to be resold to college students, the suit was brought by Basic Books, Harper \& Row, Richard D. Irwin, McGraw-Hill, William Morrow, Penguin Books USA, Prentice Hall, and John Wiley in concert with the Association of American Publishers. The suit, filed in the U.S. District Court for the Southern District of New York, seeks halting current photocopying practices and unspecified damages. Kinko's position is that their photocopying of material for course packs falls within the fair use exemptions guidelines for educational use of copyrighted materials. The suit may well have implications for academic libraries even before a decision is reached, particularly if faculty become concerned about their use of course packs and turn to the library for increased use of curriculum support materials through course reserves or other means.

\section{Legislation}

On July 26,1989 , the Senate Judiciary Commit- tee's Subcommittee on Patents, Copyrights, and Trademarks approved S. 198 amendment, the Computer Software Rental Amendments Act of 1989. The amendment, proposed by the Software Publishers Association, would establish an exemption for not-for-profit libraries allowing them to circulate software. W. David Laird, Chair of the Ad Hoc Copyright Subcommittee of ALA's Legislative Committee testified on behalf of ALA in support of this amendment on April 19, 1989. As originally written, S. 198 specifically denies an exemption to libraries lending software, even when no commercial purpose is intended or commercial gain realized on the part of the library. The S. 198 amendment is now before the full Judiciary Committee.

\section{Recent articles: Copyright andlibraries}

American Libraries, February 1989, has a series of articles on video and copyright issues.

Pitman, Randy. "AV frontier." Wilson Library Bulletin 63 (April 1989): 90-91.

Quint, Barbara. "Connect Time" column in Wilson Library Bulletin 63 (January 1989): 86, and (February 1989): 74.

Rosenberg, Victor. "Software theft and copy protection." Library Journal 114 (February 1, 1989): 46.

Turner, Judith Axler. "Parts of library associa- 
tion's photocopying policy may be used by Kinko's in its defense in lawsuit." Chronicle of Higher Education, May 10, 1989, A14.

\section{Update articles on copyright legislation}

Fields, Howard. "House gets bill fortifying intent on states vs. federal copyright." Publishers Weekly, March 24, 1989, 14.

Fields, Howard. "Supreme Court rejects second 1Ith Amendment case in month." Publishers Weekly, April 7, 1989, 36.

Fields, Howard. "House to push 1lth amendment remedy; Oman voices support." Publishers Weekly, April 28, 1989, 18.

"Software piracy bill amended to permit library lending." Library Journal 114 (May 15, 1989): 16.
"Valauskas, Edward. "Library exemption added to Software Rental Bill in U.S. Senate." Library Workstation Report 6, no.5 (May 1989): 8.

\section{Additionalinformation}

The Society of American Archivists Newsletter of March 1989 contains an excellent review of copyright news prepared by the SAA Copyright Task Force. Bob Byrd, Duke University is chair of this Task Force.

Do you have concerns or comments related to copyright issues in academic libraries? Forward to: Barbara MacAdam, Chair, ACRL Copyright Committee, Undergraduate Library, The University of Michigan, Ann Arbor, MI 48109-1185.

\section{Recruitment of underrepresented minorities}

ACRL Past President Joseph Boissé charged the Task Force on Recruitment of Underrepresented Minorities "to identify strategies which can be used to recruit to academic librarianship individuals from underrepresented minority groups; to evaluate the potential effectiveness of these strategies; and to recommend a course of action which the ACRL can pursue during the next decade."

At the first meeting of the Task Force, held at ALA Midwinter, January 9, 1989, President Boissé explained the need to form such a group. He stated that ACRL needs to more closely resemble the diversified population of the United States. This means that a greater effort to attract minority groups is imperative.

A lively brainstorming session led by Edith Fisher, Task Force chair, generated the following ideas:

- Need to recruit at the high school level;

- Need to work with other organizations, e.g., college placement groups;

- Need to solicit invitations to meetings of these groups;

- Need to reach career counselors;

- Need to talk with other groups to emphasize positive aspects of librarianship, e.g., work with technologies/information science;

- Need to spotlight minoritylibrarians in library publications;

- Need to have minority mentoring programs;

- Need to publicize those librarians making "big bucks";

- Need to emphasize that money can be made at other levels besides the director level;

- Need to network more with school librarians and other professional associations;

- Need to know more about school librarians, what they do, and use them as role models;

- Send support staff to library school/look at tuition waivers;

- Link minority librarian with minority student.

All of these ideas reconfirm what ALA's Office for Library Personnel Resources has identified as reasons for poor recruitment efforts:

1. Minority enrollment in graduate library schools is declining.

2. Lack of scholarships aimed towards minorities.

3. Status image of librarians and low salaries are a barrier.

4. Competition with other careers seems to be taking its toll.

On June 26, at ALA Annual Conference in Dallas, the Task Force discussed program ideas, various contemporary readings, and began concentrating on developing a report.

The Task Force is gathering information on strategies being used successfully in academic libraries to recruit the underrepresented. All ideas and comments can be sent to the chair or members of the Task Force: Janice Beaudin, Multicultural Outreach Coordinator, University of Wisconsin; Edith Maureen Fisher, Chair, Ethnic Studies Librarian, University of California, San Diego; Em Claire Knowles, Assistant Dean, GSLIS, Simmons College, Boston; Ichiko Morita, Associate Professor/Head-Cataloging, Ohio State University, Columbus.

The next meeting is scheduled for ALA Midwinter in Chicago, January 8, 1990, 9:30-11:00 a.m.Em Claire Knowles, Graduate School of Library and Information Science, Simmons College. 


\section{[Cambridge University Press}

\section{Americans and Their Forest}

A Historical Geography

Michael Williams

"Both a valuable resource and reference work in its field and a very readable overview of the American Conservation movement. Highly recommended." - Library Journal ISBN 0-521-33247-8 \$49.50 Hardcover

\section{The Last of the Fathers}

James Madison and the Republican Legacy

\section{Drew R. McCoy}

“...excellent and richly detailed work.... Highly recommended for large public libraries and academic libraries." - Library Journal

ISBN 0-521-36407-8 \$29.95 Hardcover

\section{Chambers-Cambridge...}

\section{Chambers Biology Dictionary}

Peter M.B. Walker, editor

Contains 10,000 definitions, including over 3000 in zoology, 2500 in botany, 1200 in biochemistry, molecular biology and genetics. Over one hundred special articles, with many illustrations, supply fuller treatments of important and difficult subjects.

ISBN 1-85296-152-X about \$34.50 Hardcover

ISBN 1-85296-153-8 about \$14.95 Paper

\section{Chambers Concise Dictionary of Scientists}

\section{Ian Millar, Margaret Millar, D. Millar, and J. Millar, editors}

Includes over one thousand concise and accessible biographies of the great men and women of science - their life histories, greatest discoveries, and their legacies today. These profiles span the centuries, from early civilization to the present day, and represent all spheres of scientific endeavor: physical, life, earth and space science. The chronological appendix and comprehensive index make cross-referencing easy and rewarding.

ISBN 1-85296-354-9 about \$29.95 Hardcover

\section{Chambers Dictionary of Synonyms and Antonyms Martin H. Manser, editor}

Provides instant answers for everyone seeking the more exact term, the livelier phrase, or the clearer expression.

ISBN 1-85296-350-6 about \$8.95 Paper

For further information, please call Joan Schwartz at 1-800-221-4512. In New York and Canada, call collect 1-212-688-8888.

\section{Cambridge University Press}

32 East 57 th Street, NY, NY 10022 